\title{
Antibodies to varicella zoster virus in the cerebrospinal fluid of neonates with seizures
}

Kirsi Mustonen, Pia Mustakangas, Marika Smeds, Laura Mannonen, Lasse Uotila, Antti Vaheri, Marjaleena Koskiniemi

\begin{abstract}
Four neonates with convulsions had IgG antibodies in their cerebrospinal fluid (CSF) to varicella zoster virus (VZV). These antibodies were found in the sera of two of these patients after the age of 6 months. Antibodies to 16 different microbes were studied from the serum and CSF of 201 neonates with neurological problems. The presence of DNA specific to HSV-1, HSV-2, and VZV in the CSF was also investigated using the polymerase chain reaction (PCR). Antibodies to VZV were detected in the CSF of four neonates. Antibody indices suggested production of VZV specific antibodies in the central nervous system. These findings suggest that intrathecal production of antibodies to VZV can appear in neonates with neurological problems, which suggests that intrauterine VZV infection can be acquired without cutaneous symptoms in the mother.
\end{abstract}

(Arch Dis Child Fetal Neonatal Ed 1998;78:F57-F61)

Keywords: varicella zoster virus; convulsions; intrathecal antibodies; cerebrospinal fluid; congenital infection

Varicella zoster virus (VZV) can cause intrauterine infections resulting in congenital varicella syndrome. Fifty affected infants have been described to date: 45 cases following maternal chickenpox and five following maternal zoster infection. The clinical manifestations were cutaneous scars (70\%), eye abnormalitieschorioretinitis, microphthalmia, Horner's syndrome, cataract, nystagmus-(66\%); abnormalities of limbs - unilateral hypoplasia of a leg, hypoplasia or absence of digits, talipes equinovarus, calcaneovalgus deformity- $(50 \%)$; brain abnormalities - cortical atrophy, mental retardation, seizures- $(46 \%)$; and poor sphincter control (32\%). Early death occurred in $28 \%$ of the cases. Other possible manifestations are chromosomal aberration, abortion, and prematurity. Herpes zoster in infancy or in childhood may be the first manifestation of intrauterine infection. ${ }^{1}$ VZV IgM antibodies, without clinical manifestations, may also be the only evidence of intrauterine infection. ${ }^{2}$ After primary infection VZV remains in the sensory ganglia and can become reactivated as herpes zoster or neurological diseases; there may be no clinical manifestations, possibly due to lowered immunity ${ }^{3}$ During pregnancy, the estimated incidence of VZV infections is 5 in 10000 or more. ${ }^{5}$ The well known and rare congenital varicella syndrome may only be the tip of the iceberg. In antibody screens of serum and cerebrospinal fluid (CSF) of 201 neurologically symptomatic neonates, we found four infants with antibodies to VZV in the CSF and these persisted in two of them after the age of 6 months. These findings are presented in this report.

\section{Methods}

The initial group for studies of viral antibody screening included 201 infants with neurological symptoms on whom a lumbar puncture had been performed for clinical reasons (suspected viral infection). The samples were collected between 1993 and 1995. All 117 boys and 84 girls were under 28 days of age at the onset of symptoms.

Children who had VZV antibodies in their CSF but no other findings were enrolled into the study. The mean age of the three boys and one girl at the onset of symptoms was 8.5 days. We selected as a reference group infants from the same group of 201 children who were born within one month of the index patients and who had similarly high VZV antibody titres but no VZV specific antibodies in their CSF. For every patient in the study group we found at least one comparable reference subject, six in all- four boys and two girls (mean age 1.3 days).

Follow up serum examinations were performed in three of the study and three of the reference subjects at over 6 months of age.

Ten serum samples from mothers of both groups were studied for specific antibodies. Samples were collected during the first trimester (National Public Health Institute, Oulu, Finland) and after delivery.

SCREENING TESTS

Assays for antibodies to HSV-1, HSV-2, VZV, respiratory syncitial virus (RSV) (commercial antigens, Virion, Wurzburg, Germany), adenovirus, influenza $\mathrm{A}$ and $\mathrm{B}$, rotavirus, Coxsackie B5, echo 22, non-typed enterovirus and parainfluenza 1 viruses (antigens grown and purified, as described by Julkunen 1984), and Mycoplasma pneumoniae (gift from $\mathrm{M}$ Kleemola, National Public Health Institute, Helsinki) were collected from serum and CSF samples using enzyme immune assay (EIA) tests. In solid phase EIA for specific IgG, antigens were used at a protein concentration of $1-5 \mu \mathrm{g} / \mathrm{ml}$ in dilution buffers to coat polystyrene microtitre plates (NUNC, Copenhagen, Denmark and Labsystems, Helsinki, Finland). Optical densities (OD) at $405 \mathrm{~nm}$ were measured from serial dilutions starting at 1:200 in serum and 1:20 in CSF, with positive 
Table 1 VZV findings and influenza A IgG antibodies for study infants (1-4) and reference (5-10) groups in three consecutive serum (S) and CSF samples, as well as antibody titres maternal sera during pregnancy (sample 1) and after delivery (sample 2)

\begin{tabular}{|c|c|c|c|c|c|c|c|c|c|}
\hline \multirow[b]{3}{*}{ Patients } & \multirow[b]{3}{*}{ Samples } & \multicolumn{8}{|c|}{ Infant samples } \\
\hline & & \multirow{2}{*}{$\begin{array}{l}\text { Age of } \\
\text { infants }\end{array}$} & \multicolumn{2}{|c|}{$\begin{array}{l}V Z V \operatorname{Ig} G(E I U) \text { of } \\
\text { infants }\end{array}$} & \multirow{2}{*}{$\begin{array}{l}\text { VZV IgG (EIU) } \\
\text { serum:CSF ratio }\end{array}$} & \multirow{2}{*}{$\begin{array}{l}V Z V \operatorname{IgG} \\
\text { antibody index }\end{array}$} & \multicolumn{2}{|c|}{$V Z V I g M$ of infants } & \multirow{2}{*}{$\begin{array}{l}\text { Influenza } A \text { IgG } \\
\text { (EIU) of infants }\end{array}$} \\
\hline & & & $S$ & $C S F$ & & & $S$ & $C S F$ & \\
\hline \multirow[t]{3}{*}{1} & I & $4 \mathrm{~d}$ & 82 & 10 & 8.2 & Not done & Not done & Negative & 116 \\
\hline & II & $11 \mathrm{~d}$ & 59 & 8 & 7.4 & 20.8 & Negative & Negative & 75 \\
\hline & III & $7 \mathrm{~m}$ & 38 & & & & Unspecified & & $<20$ \\
\hline \multirow[t]{3}{*}{2} & I & $25 \mathrm{~d}$ & 65 & 15 & 4.3 & 13.4 & Negative & Not done & 91 \\
\hline & II & $62 \mathrm{~d}$ & 66 & 8 & 8.3 & Not done & Negative & Negative & 51 \\
\hline & III & $6 \mathrm{~m}$ & $<20$ & & & & Positive & & $<20$ \\
\hline \multirow[t]{3}{*}{3} & I & $9 \mathrm{~d}$ & 86 & 11 & 7.8 & 9.3 & Negative & Negative & 103 \\
\hline & II & $57 \mathrm{~d}$ & 76 & $<5$ & Not done & Not done & Negative & Negative & 80 \\
\hline & III & $11 \mathrm{~m}$ & 24 & & & & Negativet & & $<20$ \\
\hline \multirow[t]{2}{*}{4} & I & $5 \mathrm{~d}$ & 58 & 16 & 3.6 & Not done & Positive & Not done & 36 \\
\hline & II & $25 \mathrm{~d}$ & 111 & 6 & 18.5 & 8.3 & Positive & Unspecified & 28 \\
\hline \multirow[t]{2}{*}{ Mean } & I & $10.8 \mathrm{~d}$ & 72.8 & 13 & 6 & 11.4 & & & \\
\hline & II & $38.8 \mathrm{~d}$ & 78 & 5.8 & 11.4 & 14 & & & \\
\hline Mean difference & I-II & $28.0 \mathrm{~d}$ & -5.3 & 7.3 & -5.4 & -3.0 & & & \\
\hline \multirow[t]{2}{*}{5} & I & $1 \mathrm{~d}$ & 88 & $<5$ & & & Negative & Negative & 35 \\
\hline & II & $17 \mathrm{~d}$ & 51 & Not done & & & Negative & Not done & 37 \\
\hline \multirow[t]{2}{*}{6} & I & $11 \mathrm{~d}$ & 81 & $<5$ & & & Negative & Negative & 58 \\
\hline & II & $49 \mathrm{~d}$ & 87 & Not done & & & Negative & Not done & 22 \\
\hline \multirow[t]{2}{*}{7} & I & $5 \mathrm{~d}$ & 64 & $<5$ & & & Negative & Negative & 100 \\
\hline & II & $21 \mathrm{~d}$ & 64 & $<5$ & & & Negative & Not done & 73 \\
\hline \multirow[t]{3}{*}{8} & I & $6 \mathrm{~d}$ & 75 & $<5$ & & & Negative & Negative & 75 \\
\hline & II & $21 \mathrm{~d}$ & 51 & $<5$ & & & Negative & Not done & 46 \\
\hline & III & $7 \mathrm{~m}$ & $<20$ & & & & & & $<20$ \\
\hline \multirow[t]{3}{*}{9} & I & $2 \mathrm{~d}$ & 63 & $<5$ & & & Negative & Negative & 162 \\
\hline & II & $51 \mathrm{~d}$ & 31 & $<5$ & & & Negative & Negative & 120 \\
\hline & III & $8 \mathrm{~m}$ & $<20$ & & & & Not done & & 76 \\
\hline \multirow[t]{3}{*}{10} & I & $3 \mathrm{~d}$ & 81 & $<5$ & & & Negative & Negative & 95 \\
\hline & II & $57 \mathrm{~d}$ & 46 & $<5$ & & & Not done & Negative & 70 \\
\hline & III & $6 \mathrm{~m}$ & $<20$ & & & & Negative & & $<20$ \\
\hline \multirow[t]{2}{*}{ Mean } & I & $4.7 \mathrm{~d}$ & 75.3 & & & & & & \\
\hline & II & $36 \mathrm{~d}$ & 55.0 & & & & & & \\
\hline Mean difference & I-II & $31.3 \mathrm{~d}$ & 20.3 & & & & & & \\
\hline
\end{tabular}

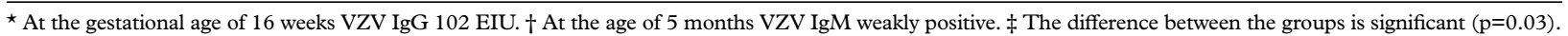

and negative controls. Enzyme immune unit (EIU) values were obtained as follows: the OD of the sample at 1:200 dilution was divided by the OD of the positive control and multiplied by 100 . EIU values $>20$ in serum and $>5$ in $\mathrm{CSF}$ were regarded as positive.

Commercial kits were used for CMV and Toxoplasma gondii (CMV IgG and IgM kit; Toxoplasma gondii IgG EIA kit, IgM EIA kit, Labsystems). For chlamydial diagnostic tests, a microimmunofluorescence method (MIF) that measures IgG and IgM antibodies specific to Chlamydia trachomatis, pneumoniae, and psittaci was used. ${ }^{7}$ PCR assays for HSV-1, HSV-2, and VZV were performed on CSF samples. Primers were selected from DNA polymerase genes for HSV-1, HSV-2, and VZV; and the PCR product was detected using luminometric microplate hybridisation. ${ }^{89}$

OTHER VIRAL TESTS

HSV and VZV specific IgM titres were assayed using commercial indirect immunofluorescence kits (Gull Laboratories, Salt Lake City, UT, USA). Positive tests were repeated after IgG inactivation (Gullsorp absorption). Antigens to herpes simplex, VZV, and respiratory syncitial virus, influenza $A$ and $B$, parainfluenza 1 and 3, and adenoviruses were studied in throat specimens using immunofluorecence. Virus culture was attempted on CSF, throat, and stool samples using four different cell lines: African GMK, Vero, human amniotic epithelial cells and human embryonic skin fibroblasts.
OTHER STUDIES

Routine CSF analysis included cell counts and analyses of glucose and total protein concentrations. Glucose was assayed amperometrically via the product of the glucose oxidase reaction using an Eppendorf EBIO 6666 analyser and the total protein by pyrogallol-red colorimetric method on a Hitacchi 717 automated chemical analyser. The assay was calibrated with Nycomed Seronorm protein and with Imro Nordic 96 (Labquality, Helsinki), the protein concentrations of which had been determined using a primary calibrator BCR CRM 470 (International Federation of Clinical Chemistry). The CSF and serum albumin as well as the CSF and serum IgG concentrations were assayed using immunoturbidimetry on a Hitachi 911 automated chemical analyser. The assays were calibrated with the IMPRO Nordic 93 standard (Labquality, Helsinki), the protein concentrations of which had been determined using the primary calibrator BCR CRM 470 (International Federation of Clinical Chemistry). The results obtained were used for calculating the CSF:serum albumin ratio (CSF albumin:serum albumin) and the CSF IgG index. The latter was calculated as the ratio CSF IgG:CSF albumin divided by the ratio serum IgG:serum albumin, ${ }^{10}$ or:

$$
\frac{\mathrm{CSF} \text { IgG index }=\mathrm{CSF} \text { IgG } \times \text { serum albumin }}{\mathrm{CSF} \text { albumin } \times \text { serum IgG }}
$$

VZV specific antibody index was calculated according to the following formula ${ }^{10}$ :

virus specific IgG in CSF in EIUs $\times$ total IgG in serum virus specific IgG EIUs in serum $\times$ total IgG in CSF 
Table 1 Continued

\begin{tabular}{|c|c|c|c|}
\hline \multicolumn{4}{|l|}{ Maternal samples } \\
\hline \multirow[b]{2}{*}{ Gestational weeks/age of infants } & \multirow{2}{*}{$\begin{array}{l}\begin{array}{l}V Z V i G G(E I U) \text { of } \\
\text { mothers }\end{array} \\
S\end{array}$} & \multirow{2}{*}{$\begin{array}{l}\text { VZV IgM of } \\
\text { mothers }\end{array}$} & \multirow{2}{*}{$\begin{array}{l}\text { Influenza A IgG } \\
\text { (EIU) of mothers }\end{array}$} \\
\hline & & & \\
\hline $6 \mathrm{~h}$ & $69^{\star}$ & Unspecified & Not done \\
\hline $16 \mathrm{~h}$ & 74 & Negative & 84 \\
\hline 62 days & 141 & Positive & 123 \\
\hline $8 \mathrm{~h}$ & 54 & Negative & 89 \\
\hline 57 days & 86 & Negative & 107 \\
\hline $14 \mathrm{~h}$ & 107 & Not done & Not done \\
\hline 25 days & 104 & Not done & Not done \\
\hline $11 \mathrm{~h}$ & 76 & & 87 \\
\hline \multirow[t]{2}{*}{48 days } & $110 \ddagger$ & & 115 \\
\hline & -32 & & -28 \\
\hline $15 \mathrm{~h}$ & 45 & Negative & 60 \\
\hline $7 \mathrm{~h}$ & 22 & Positive & 68 \\
\hline $12 \mathrm{~h}$ & 72 & Negative & 97 \\
\hline 5 days & 73 & Unspecified & 95 \\
\hline $15 \mathrm{~h}$ & 58 & Negative & 54 \\
\hline 5 days & 64 & Negative & 67 \\
\hline $10 \mathrm{~h}$ & 35 & Negative & 68 \\
\hline 2 days & 41 & Negative & 147 \\
\hline $14 \mathrm{~h}$ & 59 & Negative & 193 \\
\hline 3 days & 62 & Negative & 86 \\
\hline $12 \mathrm{~h}$ & 48.5 & & 90 \\
\hline \multirow{2}{*}{3,8 days } & 60 & & 99 \\
\hline & -11.5 & & -9 \\
\hline
\end{tabular}

EIU indicates antibody titre and it is obtained when the optical density (OD) of the sample in dilution 1:200 is compared with the OD of the positive control and multiplied by 100 . Values $\geqslant$ 100 are considered high and values $\leqslant 20$ negative in serum, and $<5$ negative in CSF.

The results were tested using the MannWhitney $U$ test. A value of $\mathrm{p}<0.05$ was regarded as significant.

\section{Results}

Four infants $(2 \%)$ with VZV IgG in the CSF had no other antibodies in the CSF nor signs of any other causes of their neurological symptoms. The reference patients had similarly high VZV antibody titres in their serum but no VZV antibodies in the CSF (table 1). In particular, none of the patients had HSV, cytomegalovirus, or $T$ gondii infection. In the reference group, one infant had Coxsackie B5 and one had influenza A IgG antibodies in the CSF. The aetiology of the neurological illnesses of the four study children remains unknown.

All four cases had weakly positive or unspecific $(n=1) \operatorname{Ig} M$ antibodies to $\mathrm{VZV}$ in the serum in at least one examination; one of them also reacted positively to the HSV IgM test. Two mothers in both groups reacted positively to the VZV IgM test.(table 1) Another reference mother had Coxsackie B5 infection that was confirmed by a diagnostic rise in serum IgG antibodies (from 43 to $180 \mathrm{EIU}$ ).

At follow up the antibody titre to VZV increased in one study infant (from 58 to 111 EIU); in the others the level remained about the same, whereas in reference subjects the level sometimes declined, although the difference between the groups was not significant. Antibodies to VZV persisted beyond the age of 6 months in two infants in the study group tested, but in none of the three reference group patients (table 1). A third child without persisting VZV antibodies was born prematurely (33 weeks) and had clinical RSV infection at the age of 25 days confirmed by positive antigen in upper respiratory secretions. She also had no persisting serum antibodies to RSV. One study group infant died at the age of 4 months with a diagnosis of chronic meningoencephalitis. Decline in serum antibodies to influenza A with age was similar in both groups and was also comparable with the decline of VZV antibodies in the reference group. One of the patients in the reference group still had influenza $\mathrm{A}$ antibodies beyond the age of 6 months and influenza $\mathrm{A}$ antibodies in the CSF as a neonate. No other patients in either group had these antibodies over the age of 6 months.

The serum:CSF VZV IgG ratio (EIU) of the study group ranged from 3.6 to 8.2 (mean 6) in the first samples, which suggests intrathecal production of antibodies. All VZV antibody indices were higher than normal $(<5)$ which supports the hypothesis that specific intrathecal antibodies are produced. The antibody titres to VZV were similar during the first trimester sera in all mothers. After delivery this was higher $(p=0.03)$ in the sera of the study group mothers than in those of the reference mothers (table 1).

In the study group the three boys were born at term, but one girl was born prematurely (33 weeks) and she had respiratory insufficiency and RSV antigen in upper respiratory secretions at the age of 25 days. All patients in the study group had convulsions. Five of the reference subjects (four boys and one girl) had convulsions and one girl had muscle hypotonia. At the time of writing none of the patients in the study group has had clinical VZV infection

The study group patients had higher red blood cell counts in the CSF than the reference group. The glucose concentration in CSF was low in one reference patient with Coxsackie B5 infection (reference values $2.2-4.5 \mathrm{mmol} / \mathrm{l}$ ). Chickenpox or herpes zoster had not been observed in any of the mothers during pregnancy.

Neither specific DNA nor virus antigen were found in any of the children. There was no significant difference between the study group and the reference group in serum VZV IgG antibodies (EIU) and serum:CSF albumin ratios. Therefore it is unlikely that VZV antibodies in the CSF of the study group could have originated from the serum. As evaluated by the CSF IgG index, intrathecal production of IgG was about the same in the study and reference groups (table 2).

\section{Discussion}

Antibodies to VZV were found in the CSF of four neonates with convulsions, and persisting serum antibodies were found in two of three of these children. The serum:CSF antibody ratios were abnormal whereas reference antibodies were negative and antibody indices to VZV were increased, which suggests production of specific antibodies to VZV in the central nervous system of these sick neonates. This is a novel finding. Only one case report has 
Table 2 Cerebrospinal fluid findings in the study (1-4) and reference (5-10) groups; $I=$ first CSF sample; II = second CSF sample

\begin{tabular}{|c|c|c|c|c|c|c|c|c|c|}
\hline Patients & $\begin{array}{l}\text { CSF } \\
\text { sample }\end{array}$ & $\begin{array}{l}\text { Age } \\
\text { (days) }\end{array}$ & $\begin{array}{l}\text { Red blood cells } \\
\left(\times 10^{6} / \mathrm{l}\right)\end{array}$ & $\begin{array}{l}\text { White cells } \\
\left(\times 10^{6} / l\right)\end{array}$ & $\begin{array}{l}\text { Glucose } \\
\text { (mmol/l) }\end{array}$ & $\begin{array}{l}\text { Total IgG } \\
(\mathrm{mg} / \mathrm{l})\end{array}$ & $\begin{array}{l}\text { Albumin } \\
(\mathrm{mg} / \mathrm{l})\end{array}$ & $\begin{array}{l}\text { CSF IgG } \\
\text { index }\end{array}$ & $\begin{array}{l}\text { CSF:serum } \\
\text { albumin ratio } \times 10^{3}\end{array}$ \\
\hline \multirow[t]{2}{*}{1} & I & 4 & 100 & 11 & 3.3 & ND & ND & ND & ND \\
\hline & II & 11 & ND & ND & ND & 46 & 301 & 0.64 & 10.4 \\
\hline \multirow[t]{2}{*}{2} & I & 25 & 795 & 2 & 4.3 & 57 & 794 & 0.64 & 26.9 \\
\hline & II & 62 & ND & ND & ND & 21 & 647 & ND & ND \\
\hline \multirow[t]{2}{*}{3} & I & 9 & 6080 & 15 & 2.9 & 89 & 822 & 0.59 & 23.2 \\
\hline & II & 57 & 4190 & 18 & 2.8 & 25 & 477 & 0.73 & 12.2 \\
\hline \multirow[t]{2}{*}{4} & I & 5 & 21 & 1 & 5.3 & ND & ND & ND & ND \\
\hline & II & 25 & ND & ND & ND & 43 & 383 & 0.42 & 15.7 \\
\hline Mean & & 24.8 & 2237 & 9.4 & 3.7 & 46.8 & 571 & 0.60 & 17.7 \\
\hline 5 & I & 1 & 0 & 4 & 3 & 122 & 915 & 0.64 & 26.2 \\
\hline 6 & I & 11 & 161 & 4 & 3.2 & ND & 627 & ND & 19.5 \\
\hline \multirow[t]{2}{*}{7} & I & 5 & 1 & 1 & 1.6 & 75 & 493 & 0.54 & 18.5 \\
\hline & II & 21 & 11 & 9 & 1.3 & 42 & 328 & 0.58 & 12.5 \\
\hline 8 & I & 6 & 1 & 16 & 3.8 & 86 & 511 & 0.52 & 13.8 \\
\hline \multirow[t]{2}{*}{9} & I & 2 & 300 & 8 & 3.0 & 119 & 877 & ND & ND \\
\hline & II & 51 & 47 & 6 & 3.1 & 126 & 822 & 0.53 & 15.0 \\
\hline 10 & I & 3 & 429 & 13 & 2.9 & 137 & 933 & ND & ND \\
\hline Mean & & 12.5 & 119 & 8 & 2.7 & 88.7 & 652 & 0.56 & 17.5 \\
\hline
\end{tabular}

$\mathrm{ND}=$ not done.

previously indicated VZV specific antibodies in the CSF of a neonate. ${ }^{12}$ That report provides no data on possible production of antibodies in the central nervous system. Moreover, in our report VZV antibodies in the patients' sera remained at the same level, whereas the level sometimes declined in the reference subjects, although the difference was not significant. Levels of reference antibodies to influenza A declined similarly in both groups. The suggested diagnosis of congenital VZV infection was confirmed by persisting antibodies over the age of 6 months in two of three of these children. A positive assay reaction to $\mathrm{VZV} \mathrm{IgM}$ was also found in all of the study group (in one this was unspecific), but in none of the reference group patients. At postnatal follow up the antibody titre to VZV in the maternal sera was significantly higher in the study group than in the reference group.

The red blood cell CSF counts were higher in the study group. Possible explanations for this may be a haemorrhagic reaction or bleeding induced by lumbar puncture. VZV infection is associated with haemorragic phenomena. ${ }^{13}$ White cell values were the same in both groups and CSF IgG indices were in line with general production of IgG.

Asymptomatic varicella infections during pregnancy have been diagnosed by the presence of specific IgM antibodies or by significant increases in maternal antibody titre, ${ }^{14}$ but it has not been reported that neonates of such mothers have neurological problems. There is one report of a neonate with convulsions without other symptoms whose mother had had chickenpox two days before labour. ${ }^{15}$ If the mother has chickenpox between 4 days before and 2 days after delivery, the mortality for infants is $30.5 \%{ }^{15}$ Perinatal varicella infections manifest at birth and on day 9 of life have been reported in infants whose mothers have not had clinical infection. ${ }^{17} 18$

The diagnosis of congenital VZV infection is problematic if the clinical picture is not typical. Even in typical cases isolation of the virus from the skin, CSF, eye and other organs has been negative. Specific $\operatorname{IgM}$ antibodies have been found in four of 11 cases. In most infants the serum antibody titre has fallen. ${ }^{1} \mathrm{VZV}$ DNA has been found in necropsy material (brain, lungs, liver, kidney or spleen) from fetuses or preterm infants whose mothers have had varicella infection during pregnancy. ${ }^{19}{ }^{20}$ In older children specific DNA has been detected in nasopharyngeal secretions, CSF, and white cells. However, it is unlikely that the virus would be found over two weeks after the infection. ${ }^{21}{ }^{22}$ One report describes negative VZV PCR in the CSF of a newborn infant with congenital varicella syndrome, ${ }^{24}$ as in our study. Evidently this does not exclude the possibility of congenital infection.

The clinical spectrum of congenital VZV infection seems to be broader than expected. Specific VZV antibodies should be measured from both serum and CSF of newborn infants with seizures. In our series four infants apparently had intrathecal production of antibodies to the virus, and congenital VZV infection may have been the cause of their neurological problems. This diagnosis was confirmed by follow up examinations of serum antibodies in two of the three children after the age of 6 months. Specific treatment is available which makes accurate diagnosis very important as it may prevent recurrent symptoms and progression of neurological injury.

We thank Dr Pentti Koskela of the National Public Health Institute, Oulu, Finland, for providing maternal sera from the first trimester for antibody studies. This study was supported by the Arvo and Lea Ylppö Foundation. MK is a member of the European Union on Concerted Action on Viral Meningitis and Encephalitis.

1 Gershon AA. Chickenpox, measles and mumps. In: Remington JS, Klein JO, eds. Infectious diseases of the fetus $\mathbb{E}$ newborn infant. 4th edn. Philadelphia: WB Saunders, newborn infant.

2 Paryani SG, Arvin AM. Intrauterine infection with varicella-zoster virus after maternal varicella. $N$ Engl f Med 1986;314:1542-6.

3 Mayo DR, Booss J. Varicella zoster associated neurologic disease without skin lesions. Arch Neurol 1989;46:313-5.

4 Gilden DH, Dueland AN, Devlin ME, Mahalingam R. Varicella-zoster virus reactivation without rash. $\mathcal{F}$ Infect $D i$ is 1992;166(Suppl 1):S30-4

5 Sever JA, White LR. Intrauterine viral infections. Anпu Rev Med 1969;19:471-86.

6 Julkunen I, Kleemola M, Hori T. Serological disgnosis of influenza $\mathrm{A}$ and $\mathrm{B}$ infections by enzyme immunoassay: comparison with the complement fixation test. F Virol Methods 1984;1:7-14.

7 Wang SP, Grayston JT. Human serology in Chlamydia trachomatis infection with microimmunofluorescene. $\mathcal{F}$ Infect Dis 1974;130:388-97.

8 Vesanen M, Piiparinen H, Kallio A, Vaheri A. Detection of herpes simplex DNA in cerebrospinal fluid samples using 
polymerase chain reaction and microplate hybridization. $\mathcal{F}$

Virol Methods 1996; 59:1-11.
9 Koskiniemi M, Mannonen L, Kallio A, Vaheri A. Luminometric microplate hybridization for detection of varicellazoster virus PCR product from cerebrospinal fluid. $\mathcal{F}$ Viro Methods 1997;12:71-79.

10 Delpech B, Lichtblau E. Etude quantitative des immunoglobulines $\mathrm{G}$ et de l'albumine du liquide cephalo rachidien. Clin Chim Acta 1972;37:15-23.

11 Ukkonen P, Granstrom ML, Räisänen J, Salonen EM, Penttinen $\mathrm{K}$. Local production of mumps $\mathrm{IgG}$ and $\operatorname{IgM}$ antibodies in the cerebrospinal fluid of meningitis patients. 7 Med Virol 1981;8:257-65.

12 Bennet R, Forsgren M, Herin P. Herpes zoster in a 2-weekold premature infant with possible congenital varicella encephalitis. Acta Paediatr Scand 1985;74:979-81.

13 Kleinschmidt-DeMasters BK, Amlie-Lefond C, Gilden $\mathrm{DH}$. The patterns of varicella zoster virus encephalitis. Hum Pathol 1996;27:927-38.
Hum

14 Gruninger T, Dobec M, Keller A. Asymptomatic varicella infections in pregnancy: detection and problems. Gynekol infections in pregnancy: detection and

15 Wutzler P, Sauerbrei A, Scholz H, Wiederberg H. Varizellazoster virusinfektionen in der schwangerscaft. Pädiat Prax 1990;41:213-24.

16 De Nicola LK, Hanshaw JB. Congenital and neonatal varicella. F Pediatr 1979;94:175-6.
17 Pridham FC. Chicken-pox during intrauterine life. BMf 1913;i: 1054 .

18 Newman CGH. Perinatal varicella. Lancet 1965; ii:1159-61.

19 Michie CA, Acolet D, Charlton R, et al. Varicella-zoster contracted in the second trimester of pregnancy. Pediatr Infect Dis F 1992;11:1050-3.

20 Puchhammer-Stöckl E, Kunz C, Wagner G, Enders G. Detection of varicella-zoster virus (VZV) DNA in fetal tis1994;22:65-9.

21 Ozaki T, Matsui Y, Kido S, Yamanishi K. Varicella zoster virus DNA in throat swabs. Arch Dis Child 1990; 65:333-34.

22 Puchhammer E, Popow-Kraupp T, Heinz FX, Mandl CW, Kunz C. Detection ot varicella-zoster virus DNA polymerase chain reaction in cerebrospinal fluid of patients suffering from neurological complications associated with chicken pox or herpes zoster. F Clin Microbiol 1991;29:1513-6.

23 Ozaki T, Kajita Y, Asano Y, Aono T, Yamanishi K. Detection of varicella-zoster virus DNA in blood of children with varicella. $\mathcal{F}$ Med Virol 1994;44:263-5.

24 Enders G, Miller E, Cradock-Watson J, Bolley I, Ridgehalg $M$. Consequences of varicella and herpes zoster in pregnancy: prospective study of 1739 cases. Lancet 1994;343:1547-50 